\title{
A clinicopathological case of retinopathy of prematurity (ROP) treated by peripheral cryopexy
}

\author{
I. NISSENKORN, ${ }^{1}$ I. KREMER, ${ }^{1}$ I. BEN SIRA, ${ }^{1}$ S. COHEN,${ }^{1}$ AND A. GARNER ${ }^{2}$ \\ From the ${ }^{1}$ Department of Ophthalmology, Beilinson Medical Center, Petah-Tiqva, and \\ Tel Aviv University Sackler School of Medicine, Israel, and the ${ }^{2}$ Department of Pathology, \\ Institute of Ophthalmology, London
}

SUMMARY A baby born at 25 weeks gestation with a birth weight of $800 \mathrm{~g}$ who suffered from severe respiratory distress syndrome with metabolic acidosis is described. Active retinopathy of prematurity, stages II and III, was found in the right eye at the age of 1 month and in the left eye a month later. Both eyes were treated by peripheral cryopexy. The pathological examination showed that cryopexy was effective in preventing progression of the retinopathy to cause severe cicatrisation.

Several studies ${ }^{1-7}$ have confirmed that the severity and prevalence of the retinopathy of prematurity (ROP) are related to the degree of retinal prematurity or in other words to the extent of the zone of avascular retinal tissue. It may be assumed that the development of ROP is triggered by a vasoproliferative substance produced in the ischaemic (hypoxic) retina, as happens in other ischaemic retinopathies. The greater the stimulus in the area of the ischaemic retina to produce this substance, the greater the vasoproliferation and the consequence of cicatrisation. As in other ischaemic retinopathies, destruction of the ischaemic tissue is believed to reduce the formation of this vasoproliferative factor and so arrests the disease. ${ }^{8}$

Although some investigators, mainly those from Japan, ${ }^{9-12}$ have shown that treatment by laser photocoagulation in stages II and III can arrest the disease and prevent the severe cicatricial stage, others have not been able to confirm that the late complications of ROP can be prevented by laser or cryocoagulation. ${ }^{13}$ In this clinicopathological case we present our method and the results of treatment of this disease.

\section{Case report}

During the first hour of life a female preterm infant, who was born at 25 weeks gestation with a weight of $800 \mathrm{~g}$, developed mild respiratory distress with tachypnoea. The blood gases without oxygen treatogy, Beilinson Medical Center, 76100 Petah-Tiqva, Israel. ment were: $\mathrm{Po}_{2}=57$ torr; $\mathrm{PCO}_{2}=47$ torr; $\mathrm{pH}=7 \cdot 19$, and $\mathrm{BE}=-9.9 \mathrm{mEq}$.

$$
\frac{\text { lit }}{\text { lit }}
$$

Two hours later she developed cyanosis and was treated with oxygen at a concentration of $25 \%$, which was increased to a level of $30 \%$ on the second day of life. An $x$-ray diagnosis of hyaline membrane disease was then made. When receiving an oxygen concentration of $25-30 \%$ her blood $\mathrm{Po}_{2}$ was about 60 torr, and $\mathrm{CO}_{2}$ level was normal; nevertheless she developed metabolic acidosis with $\mathrm{pH}$ levels of $7 \cdot 19$ to $7 \cdot 24$. Other blood test results were normal.

From the 4th day of life she suffered from severe attacks of apnoea with cyanosis and was treated by artificial respiration with inspired $\mathrm{Po}_{2}$ levels up to

\section{Table 1 Classification of ROP and RLF}

\begin{tabular}{|c|c|c|c|}
\hline \multicolumn{2}{|c|}{$\begin{array}{l}\text { Active retinopathy of } \\
\text { prematurity }(R O P)\end{array}$} & \multicolumn{2}{|c|}{$\begin{array}{l}\text { Cicatricial retrolental fibroplasia } \\
(R L F)\end{array}$} \\
\hline I & $\begin{array}{l}\text { Demarcation line with or } \\
\text { without recognizable }\end{array}$ & I & $\begin{array}{l}\text { Peripheral pigmentary } \\
\text { changes }\end{array}$ \\
\hline & $\begin{array}{l}\text { abnormal peripheral } \\
\text { vascularisation }\end{array}$ & II & $\begin{array}{l}\text { Disc and vessels distortion } \\
\text { and angle of temporal veins }\end{array}$ \\
\hline II & Ridge & & and fibrotic mass in \\
\hline III & Presence of a ridge with & & periphery \\
\hline & $\begin{array}{l}\text { extra retinal fibrovascular } \\
\text { proliferation }\end{array}$ & III & $\begin{array}{l}\text { Retinal fold and fibrotic } \\
\text { mass in periphery }\end{array}$ \\
\hline IV & $\begin{array}{l}\text { Retinal detachment: } \\
\text { (a) Serous } \\
\text { (b) Traction } \\
\text { (c) Combined of serous } \\
\text { and traction }\end{array}$ & IV & Retrolental mass \\
\hline
\end{tabular}


$70 \%$ in the 4 th week of life. She then developed congestive heart failure. A diagnosis of patent ductus arteriosus was made, and she underwent surgical closure of the arterial duct. After the operation she developed severe heart failure with severe hypoxaemia $\left(\mathrm{Po}_{2}\right.$ below 40 torr) and metabolic acidosis, which caused her death at the age of 6 months.

The first ophthalmological examination was performed at 2 weeks of age. The anterior segments of both eyes were normal, without pupillary rigidity or iris vessel dilatation. The findings in the acute phase of the retinopathy were recorded on the basis of a new international classification due to be published shortly (Table 1). Grading of the cicatricial phase was according to the classification of Patz and Reese. ${ }^{14}$

Fundus examination revealed, in the right eye, vitreous haze in the temporal periphery. The papilla, large vessels, and macular reflexes were normal. The vessels extended to the macular area (zone Iaccording to the new classification). An avascular area was found from 12 to 12 o'clock, i.e., 12 hours. Examination of the left eye revealed a vitreous haze in the temporal periphery, but the papilla, large vessels, and macula were found to be normal. The retinal vessels reached the macular area only (zone I), with an avascular area seen from 12.00 to 12.00 o'clock-12 hours.

Two weeks later, at the age of 1 month, examination of the right eye revealed a normal anterior segment. In the fundus active stage II ROP was found; a ridge was found from 12 to 12 o'clock in zone II with retinal and extraretinal vasoproliferation from 12 to 6 o'clock (stage III).

In the left eye the anterior segment was normal. Fundus examination showed active stage II ROP from 12 to 12 o'clock (12 affected hours). According to our criteria ${ }^{8}$ we decided to treat the right eye (which was the more severely affected) by cryopexy. We treated the avascular areas of the retina anterior to the neovascularisation tufts (12 hours). No special postoperative treatment was applied. A week after the cryopexy the right eye fundus showed arrest of the active stage and less engorged peripheral vessels. Three weeks later we saw a continuation of normal vessels between the chorioretinal scars, and at the age of 2 months there was a picture of cicatricial stage of retrolental fibroplasia-grade I (Table 1). At that time (age 2 months) examination of the left eye showed pupillary rigidity, and fundus examination showed active stage II zone II disease, with a ridge from 12.00 to 12.00 o'clock (12 affected hours). Retinal and extraretinal fibrovascular proliferation (stage III) was seen from 12.00 to 6.00 o'clock, and from 2.00 to 5.00 o'clock a serous retinal detachment was found posterior to the ridge (stage IV).

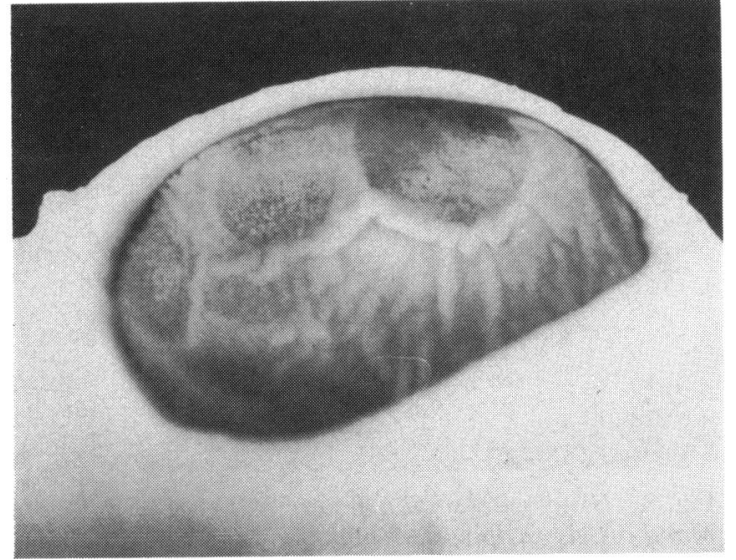

Fig. 1 A macroscopical picture showing 3 chorioretinal scars after cryoapplication. Posterior to the scars there are post-mortem retinal folds $(R E)$.

At this time we decided to treat this eye with cryopexy from 12.00 to 12.00 o'clock (12 hours). Two weeks after treatment the active ROP was arrested, and 2 weeks later, at the age of 3 months, cicatricial stage II RLF was found. The angle between large vessels was $100^{\circ}$, but there was no displacement of the macula. A small fibrotic mass was seen in the temporal periphery.

\section{PATHOLOGICAL FINDINGS}

Macroscopic examination of both eyes revealed no external abnormality. The peripheral retina,

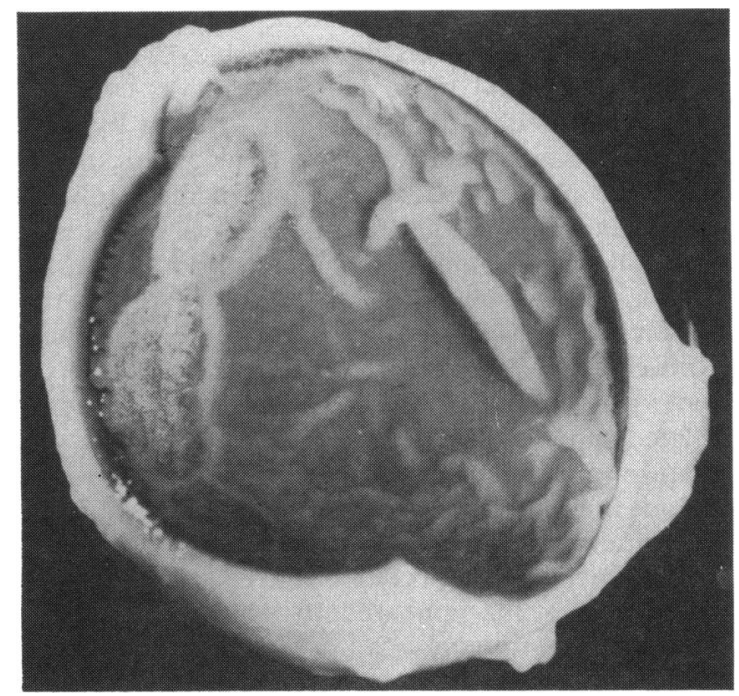

Fig. 2 A macroscopical picture showing 2 confluent chorioretinal scars after cryoapplication; posteriorly there is a prominent post-mortem retinal folding $(R E)$. 


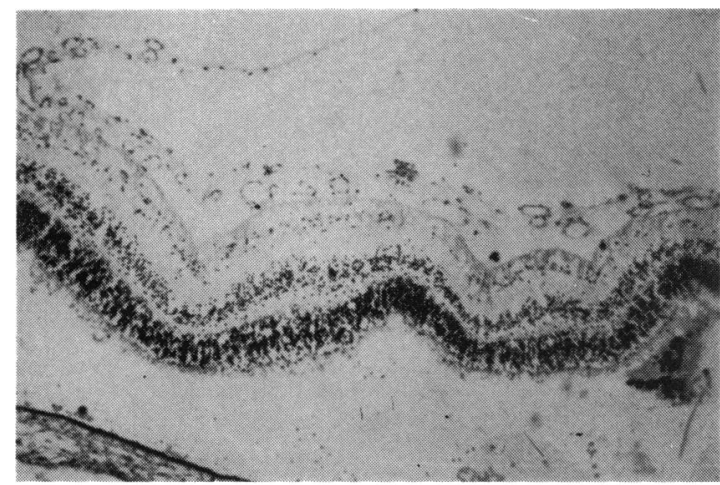

Fig. 3 Histological section showing a layer of newly formed blood vessels on the surface of the retina near the temporal periphery in a region between 2 coagulated spots (RE).

(Haematoxylin and eosin, $\times 120$ ).

especially on the temporal side, was largely destroyed by a ring of circular chorioretinal scars, while the edge of the residual neuroretina was elevated to create a scalloped ridge throughout virtually the total circumference (Fig. 1). Elsewhere there was postmortem folding of the retina (Fig. 2). Vitreous veils were seen only in the left eye, especially towards the equator. No abnormality was seen in the anterior segment of either eye.

\section{RIGHT EYE}

On microscopical examination of the right eye the posterior retina and the optic nerve head were normal, except for detachment and autolysis of the rods and cones due to post-mortem changes. On the nasal side the retina was vascularised up to the site of a cryocoagulation burn. Here there was complete absence of neural tissue and replacement by loose glial fibres; the pigment epithelium was also destroyed with migration of residual melanin pigment towards the inner surface. A few residual vessels were seen in the underlying choroid. On the temporal side the sections passed between the treated zones, so that 'intact retina' was seen as far as its normal limits. Between $4-5 \mathrm{~mm}$ proximal to the ora serrata the inner surface of the retina was overlaid by a layer of dilated blood vessels (Fig. 3). These vessels were mature (most of them had pericytes) and contained blood; they were lying flat against the inner limiting membrane, except at the posterior edge, where they were attached to a strand of vitreal material. The underlying retina appeared to be vascularised. In retinal digest preparations the vessels were chiefly in the form of loops in the areas of cryotherapy burns (Fig. 4). Elsewhere, the most peripheral vessels were in the form of dilated tortuous loops related to feeder vessels, which were also dilated and hypercellular

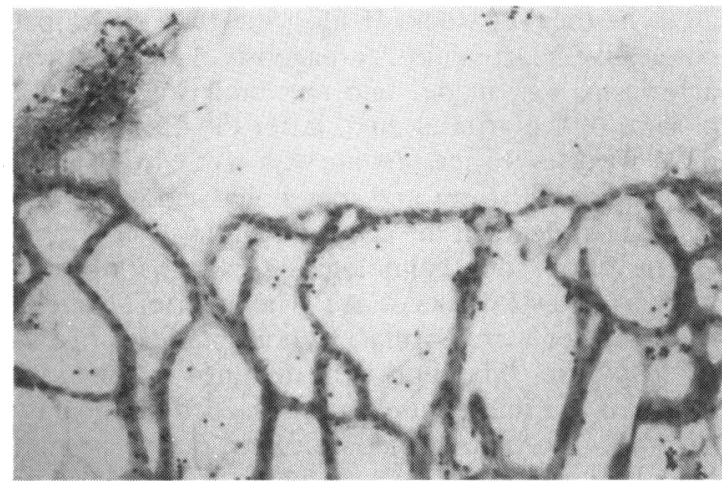

Fig. 4 Retinal digest preparation showing capillary loops or 'arcades' in the edge of the capillary bed near a

cryotherapy burn (RE). (Haematoxylin and eosin, $\times 195)$.

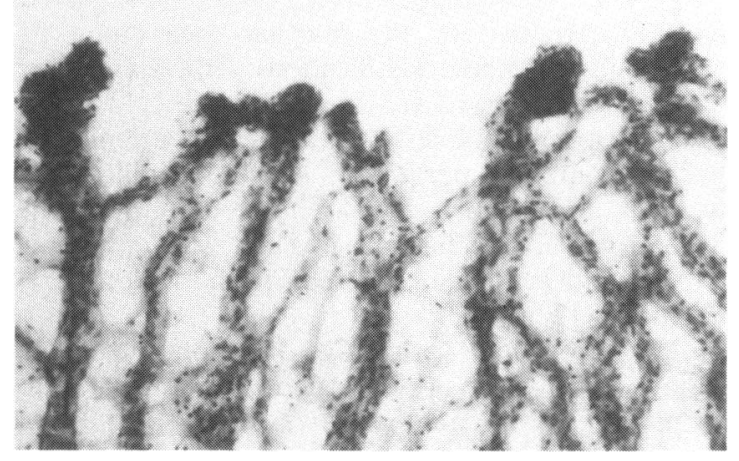

Fig. 5 Retinal digest preparation showing dilated tortuous and hypercellular capillary loops related to feeder vessels which are also dilated and hypercellular (RE).

(Haematoxylin and eosin, $\times 195$ ).

(Fig. 5). There were numerous, apparently blind capillary loops in the more proximal vasculature; such loops were hypercellular and probably represented a limited proliferative response to preceding vasoobliteration (Fig. 6). Figure 7 shows capillary loops (or 'shunts') at the retinal periphery bordering a cryoapplication scar. Distally, pigment was seen where cryotherapy had been applied.

\section{LEFT EYE}

Other than detachment secondary to post-mortem autolysis, microscopical examination showed that the neuroretina from the disc to the level of the cryocoagulation was normal and that the pigment epithelium was intact. Normal blood capillaries reached to the crest of a circumferential retinal fold at the limit of vascularisation, where there was seen a little increase in endothelial cell concentration. Immediately beyond the retinal fold both the retina 


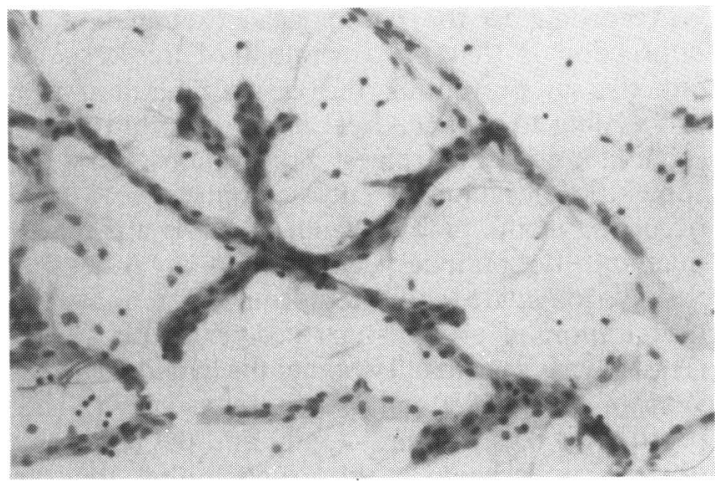

Fig. 6 Retinal digest preparation showing several bizarre hyperplastic capillaries which lie well back from the periphery and are presumed to be intraretinal $(R E)$. (Haematoxylin and eosin, $\times 195$ ).

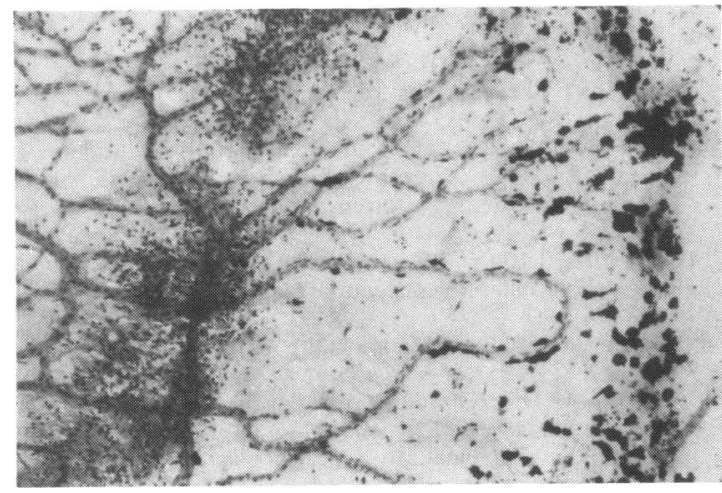

Fig. 7 Retinal digest preparation showing capillary loops (or 'shunts') at the retinal periphery. Distally pigment is seen where cryotherapy has been applied (RE). (Haematoxylin and eosin, $\times 120)$.

and the choroid were effectively destroyed, being represented by a little loose fibrillar tissue (possibly glial), and isolated melanin-containing cells (Fig. 8). More peripherally there was absence of blood vessels and some pigment disturbance with intraretinal migration. The peripheral choroid was normal. There was no sign of preretinal neovascularisation. In a digest preparation the retinal vessels showed a normal arrangement with clearly defined periarterial capillary free zones. Some venules showed segments in which there was hypercellularity, but there was no associated dilatation, and its significance is obscure (Fig. 9). At the edge of the vascular system the arrangement was characterised by blind loops, some of which were both hypercellular and mildly dilated (Fig. 10). A tangled network of glial tissue surrounded the peripheral capillaries, being maximal slightly proximal to the most peripheral vessels.

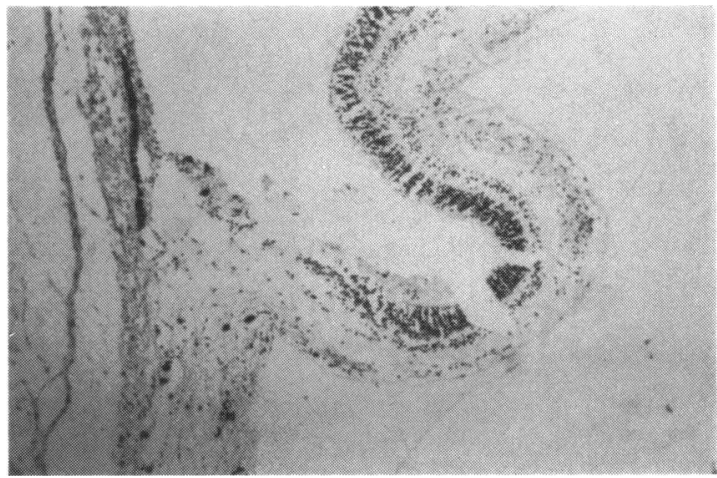

Fig. 8 A histological section of retina at its junction with a cryocoagulated area. Blood vessels in the nerve fibre and ganglion cell layers reach to the top of the artefactual fold where there is a concentration of proliferating endothelial cells. The treated area shows loss of neural tissue and a residual glial scar (LE). (Haematoxylin and eosin, $\times 120)$.

\section{Discussion}

Several investigators ${ }^{1415}$ have proved that the early avascular retina is invaded by a wave of spindle shaped mesenchymal cells, originating in the optic disc at 16 weeks gestational age. As these cells move peripherally they leave cords of cells which become canalised to form a very dense primitive capillary network. This network develops into arterioles, venules, and mature capillaries, which reach the nasal periphery in the 36th week of gestation and the temporal periphery in the 40th week. Thus we find a combination of several aetiopathological factors related specifically to the preterm retina: $(a)$ a wide area in the retinal periphery which is avascular; $(b)$ a toxic effect of oxygen and other metabolic factors on the capillary endothelium. ${ }^{16-19}$ The latter damages the most recently formed vessels and inhibits further capillary development, while the sensory retina continues to mature and consumes more oxygen. These factors combined may eventually cause peripheral retinal ischaemia when the supplementary oxygen is withdrawn. A vasoproliferative stimulus is then initiated, probably by the release of angiogenic substances from the hypoxic area, which causes the proliferation of new vessels (neovascularisation) in the border between the normal and hypoxic zones. These vessels, some of which lie on the inner surface of the retina, lack tight junctions and so tend to leak and bleed into the retina and vitreous, with resultant fibrosis and traction retinal detachment. Accordingly we can identify 2 main phases in this disease-the ischaemic phase and the vasoproliferative phase, which leads to the severe complications of ROP. ${ }^{20-22}$

Since ROP shows the characteristics found in other 


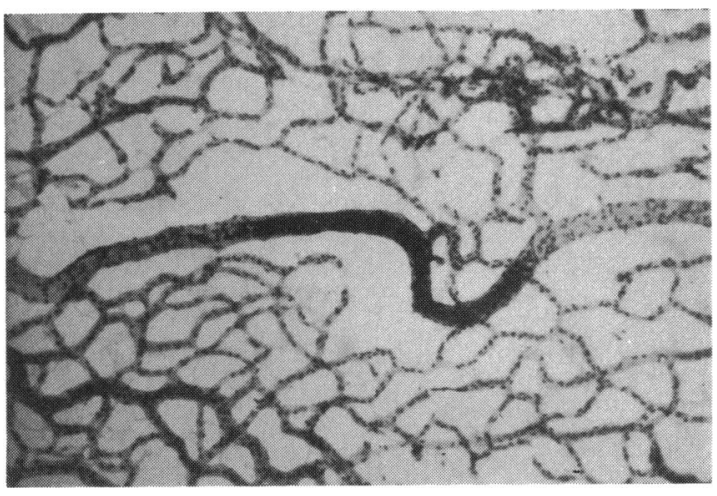

Fig. 9 A retinal digest preparation of $L E$ showing a vein running across the centre of the picture with segmental cellular hyperplasia; its significance is obscure but suggests a limited focal response to continued angiogenic stimulation. (Haematoxylin and eosin, $\times 195$ ).

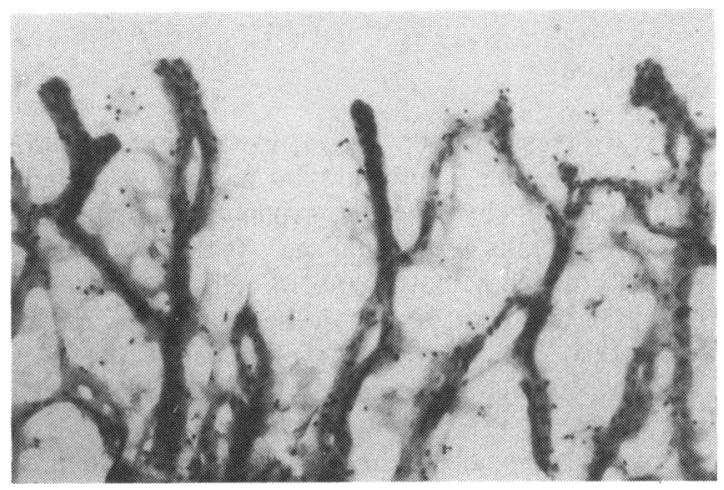

Fig. 10 A retinal digest preparation of $L E$ showing capillary loops at the edge of the vascular system, some of which are both hypercellular and dilated. (Haematoxylin and eosin, $\times 195$ ).

ischaemic retinopathies, it was logical that methods of treating these retinopathies, such as photocoagulation and cryopexy, should be tried in the treatment of ROP as well. ${ }^{812}$ Conflicting results have been obtained by this approach, ${ }^{13}$ probably owing to the lack of clear indications as to the optimal time of treatment and the exact method to be used. One of the studies which showed discouraging results was that of Kingham. ${ }^{13}$

Since 1976 peripheral cryopexy has been performed in our department in active stage III ROP with the use of the indirect ophthalmoscope under local anaesthesia. Cryoagulation is applied transconjunctivally directly over the peripheral avascular retina, anterior to the tufts of neovascularisation. Each location is frozen only once, to avoid freezing the neovascularisation fronds themselves.
According to the pathological examination our impression is that the treatment of this case was effective in preventing the vasoproliferation from proceeding to the cicatrical phase. The histological sections and retinal digest preparations show that some proliferation of new capillaries was still occurring at the time of death, but this was limited mainly to the periphery, in the small areas between the cryocoagulated spots. Unfortunately retinal digest preparations give a 2-dimensional picture only, and it is not always easy to tell whether the hyperplastic new vessels are intraretinal or on the surface. Their position at the extreme margin, and the absence of obvious underlying vessels, suggest that they are essentially intraretinal.

\section{References}

1 Kingham JD. Acute retrolental fibroplasia. Arch Ophthalmol 1977; 95: 39-47.

2 Kinsey VE, Arnold $\mathrm{HJ}$, Kalina RE, et al. $\mathrm{Pa}\left(\mathrm{O}_{2}\right)$ levels and retrolental fibroplasia: a report of the cooperative study. Pediatrics 1977; 60: 655-68.

3 Kinsey VE, Zacharias L. Retrolental fibroplasia: incidence in different localities in recent years, and a correlation of the incidence with treatment given the infants. JAMA 1949; 139: 572-8.

4 Johnson L, Schaffer D, Boggs TR. The premature infant, vitamin E deficiency and retrolental fibroplasia. Am J Clin Nutr 1974; 27: 1158-73.

5 Majima A. Studies on retinopathy of prematurity; statistical analysis of factors related to occurrence and progression in active phase. Jpn J Ophthalmol 1977; 21: 404-20.

6 Shochat M, Reisner S, Nissenkorn I, Yassur Y, Ben-Sira I. Retinopathy of prematurity-incidence and risk factors. $\mathrm{Br} J$ Ophthalmol in press.

7 Keith LG, Smith S, Landsdell B. Retrolental fibroplasia a study of the incidence and aetiological factors 1977-79. Med J Aust 1981 ; ii: 589-92.

8 Ben-Sira I, Nissenkorn I, Grunwald E, Yassur Y. Treatment of acute retrolental fibroplasia by cryopexy. Br J Ophthalmol 1980; 64: 758-62.

9 Nagata M, Yamagishi N. Treatment of acute proliferative retinopathy of prematurity with xenon arc photocoagulation. Retinopathy of prematurity conference, Washington, DC, 4-6 December 1981: 2: 772 .

10 Ohima K, Kano IH, Ikui H. Clinical study and photocoagulation of retinopathy of prematurity. Folia Ophthalmol Jpn 1971; 2: $700-7$.

11 Nagata M, Tsuruoka Y. Treatment of acute retrolental fibroplasia with xenon arc photocoagulation. Jpn J Ophthalmol 1972; 16: 131-43.

12 Mazima A, Takahashi M, Hibino Y. Clinical observations of photocoagulation on retinopathy of prematurity. Jpn J Clin Ophthalmol 1976; 30: 93-7.

13 Kingham JD. Acute retrolental fibroplasia. II. Treatment by cryosurgery. Arch Ophthalmol 1978; 96: 2049-53.

14 Reese AB, King M, Owens WC. A classification of retrolental fibroplasia. Am J Ophthalmol 1953; 36: 1333-5.

15 Ashton $\mathrm{N}$. Retinal angiogenesis in the human embryo. Br Med Bull 1970; 26: 103-6.

16 Hittner $\mathrm{H}$, Kretzer F. Ultrastructure of spindle cells in high-risk preterm infants, as modulated by oxygen and vitamin E. Presented at the New York Academy of Sciences Conference on vitamin E. 11-13 November 1981. 
17 Campbell K. Intensive oxygen therapy as a possible cause of retrolental fibroplasia: a clinical approach. Med J Aust 1951; ii: 48-50.

18 Patz A, Hoeck LE, De La Cruz E. Studies on the effect of high oxygen administration in retrolental fibroplasia. $\mathrm{Am} J$ Ophthalmol 1952; 35: 1248-53.

19 Ashton N. Oxygen and the growth and development of retinal vessels. In: Kimura, SJ, Caygill WM, eds. Vascular complications of diabetes mellitus. St Louis: Mosby, 1967: 3-32.

20 Bawol RD, Flynn JT, Cassady J, et al. Acute proliferative retro- lental fibroplasia, multivariate risk analyses. Presented at ROP Conference, 4-6 December 1981. Washington DC.

21 Reese AB, Blodi FC, Locke JC. The pathology of early retrolental fibroplasia with an analysis of the histologic findings in the eyes of newborns and stillborn infants. Am J Ophthalmol 1952; 35: $1407-26$.

22 Kushner BJ, Essner D, Cohen IJ, Flynn JT. Retrolental fibroplasia. II. Pathologic correlation. Arch Ophthalmol 1977; 95: 29-38. 